\title{
Ekstraksi Pektin dari Kulit Buah Coklat dengan Pelarut Asam Sitrat
}

\author{
Susilowati,Siswanto Munandar,Luluk Edahwati,Tutuk Harsini \\ Fakultas Teknologi Industri ,UPN"Veteran"Jatim \\ Program Studi Teknik Kimia \\ Email:zuzituhu@yahoo.com
}

\begin{abstract}
Abstrak
Tanaman coklat (Theobroma cacao) adalah tanaman yang banyak dijumpai di Indonesia terutama dari perkebunan. Tanaman coklat terbagi menjadi 3 bgian yaitu kulit, daging buah dan biji. Namun selama ini dalam pemanfaatannya hanya daging buah dan bijinya saja yang diambil, sedangkan kulitnya kurang dimanfaatkan, merupakan buangan yang banyak dan biasanya digunakan sebagai pakan ternak. Kulit coklat merupakan salah satu sumber pektin. Pektin dalam industri pangan adalah sebagai bahan pengental, dan juga sebagai bahan tambahan pada pembuatan selai, jelly, marmalade. Pengambilan pektin dari kulit buah coklat dilakukan dengan proses ekstraksi dan memakai pelarut asam sitrat. Pada kondisi operasi $\mathrm{pH} 3$, perbandingan bahan dan pelarut 1:12, 1:14, 1:16, 1:18, 1: 20, waktu operasi 75 menit, 100 menit, 125 menit, 150 menit, 175 menit pada suhu $80{ }^{\circ} \mathrm{C}$. Dengan pencuaian memakai alkohol dan tanpa alkohol. Dari hasil peneltian diperoleh kadar metoksil 42,80\% pada pencucian alkohol dan kadar metoksil 42,68\% pada pencucian tanpa alkohol. Perbandingan pelarut yang terbaik pada 1: 18 dan waktu ekstraksi 150 menit. Perlakuan pada pencucian dengan alkohol dan tanpa alkohol menghasilkan kadar metoksil yang hampir sama, tetapi dari segi warna pda pektin untuk pencucian dengan alkohol menghasilkan warna yang bersih dan putih.
\end{abstract}

Kata kunci : Asam sitrat, Ekstraksi, Kulit buah coklat, Pektin.

\begin{abstract}
Cocoa (Theobroma cacao) is a plant which is often found Indonesia, especially from plantations. Cocoa is into 3 sections, that is peel, fruit's flesh and seeds. But so far in its use only cocoa flesh and seeds are taken to be used. While the peel is less utilized, becames a lot of waste and is usually used as animal's feed. Cocoa peel is a source of pectin. Pectin in the food industry is a thickener and an additive in manufacturing jam, jelly, marmalade etc. Process of taking pectin from cocoa peel is done by extraction with citric acid solvent at operating condition $\mathrm{pH} 3$, material and solvent ratio of $1: 2,1: 14,1: 16,1: 18,1: 20$, operation time of 75 minutes, 100 minutes, 125 minutes, 150 minutes, and 175 minutes, at $80{ }^{\circ} \mathrm{C}$ and washing with alcohol and without alcohol. From the result of the research it is obtained that methoxyl content is $42.80 \%$ on washing with alcohol and $42.86 \%$ on washing without alcohol. The best comparison of solvent is at 1:18 and 150 minutes of extraction time. Treatment on washing with alcohol and without alcohol produces methoxyl content which is almost same, but is terms of color on pectin washing with alcohol produces a clean and white color.
\end{abstract}

Key words: Citric Acid, Extraction, Cocoa peel and Pectin.

\section{Pendahuluan.}

Kulit buah coklat merupakan salah satu sumber pektin. Kandungan pektin yang terdapat dalam kulit buah coklat sekitar $6-12 \%$ pektin tiap-tiap berat kering (Spillane.1995) Pemanfaatan tanaman coklat selama ini masih terbatas yaitu pada bijinya, sedangkan bagian lainnya seperti kulit buah dan pulp belum banyak dimanfaatkan. Melihat dari data statistik, kebutuhan pektin dikawasan asia, termasuk juga indonesia pada tahun 2000 sampai 2009, bahwa konsumsi pektin terus mengalami peningkatan. (Repository. usu. ac.id.2012) . Untuk mengatasi kebutuhan akan pektin, maka bisa dimanfaatkan limbah kulit coklat tersebut untuk diolah dan diambil pektinnya. Sehingga kebutuhan pektin dapat terpenuhi dan bermanfaat, serta akan mengurangi pencemaran lingkungan dari limbah kulit coklat tersebut. Pektin adalah senyawa polisakarida yang larut dalam air dan merupakan asam-asam pektinat yang mengandung gugus-gugus metoksil, fungsi utamanya sebagai bahan pengental dan pembentuk gel. Selain dalam industri makanan pektin dapat digunakan dalam industri kosmetik dan farmasi , seperti dalam pembuatan krim, sabun,minyak rambut dan pasta. Mutu pektin terlihat dari jumlah kandungan metoksilnya, bila kandungan metoksilnya 2,3 sampai $4,5 \%$ termasuk pektin metoksil 
rendah., dan bila kandungan metoksilnya lebih dari 7,12 $\%$ termasuk pektin metoksil tinggi.(D.Mariaty.2000). Karena kandungan metoksil pada pektin ini akan mudah menjadi bentuk jelly, merupakan sifat penting dari pektin. Penggunaan pektin dalam industri pangan ditentukan oleh kadar metoksil dari pektin tersebut, pektin dengan kadar metoksil tinggi biasanya digunakan untuk jam, jelly , pembuatan kembang gula berkualitas tinggi, pengentalan untuk minuman, emulsi flavor. Pektin dengan kadar metoksil rendah biasanya digunakan jam dan jelly berkalori rendah untuk orang - orang yang menghindari gula, digunakan juga untuk puding dan gel buah buahan dalam es krim.( C.Schemin M.H.,et al.2005). Pektin diperoleh dari kulit buah coklat dengan cara ekstraksi. Ekstraksi adalah proses pemisahan satu atau beberapa bahan dari suatu padatan atau cairan, pemisahan tersebut terjadi atas dasar kemampuan larut yang berbeda - beda dari masing - masing komponen yang ada dalam campuran.(Mc Cabe.2001). Dalam ekstraksi ini digunakan pelarut air dengan ditambahkan asam sitrat, asam laktat, asam formiat, ethyl asetat hingga $\mathrm{pH} 3$. Penambahan asam bertujuan untuk menghidrolisis protopektin menjadi pektin.( eprint.undip.ac.id.2011).

\section{Bahan dan Metode.}

\section{Persiapan Bahan.}

Kulit buah coklat yang telah kering kering dihaluskan dan diayak dengan ukuran 50 mesh.

\section{Ekstraksi}

Timbang 100 gram, dimasukkan pada labu leher tiga dan diberi pelarut, sesuai dengan variabel perbandingan bahan dan pelarut, yaitu $1: 12,1: 14,1: 16,1: 18$ dan 1:20 , dengan pelarut asam sitrat. Waktu ekstraksi : 75 menit, 100 menit, 125 menit, 150 menit dan 175 menit. Suhu ekstraksi $80^{\circ} \mathrm{C}$. , pH 3, kecepatan pengadukan $600 \mathrm{rpm}$.

\section{Pengentalan}

Setelah proses ekstraksi hasilnya disaring, diambil filtrat nya dan dilakukan pemanasan. Pemanasan bertujuan untuk menguapkan air, dipanaskan volumenya hingga separuh dari volume mula-mula. Sehingga filtrat menjadi agak kental.

\section{Pengendapan}

Pengendapan dengan menggunakan alkohol asam, yang tujuannya untuk memisahkan pektin dari pelarutnya. Filtratnya diberi alkohol asam.(alkohol ditambah asam sitrat dengan perbandingan 1:1,5) dibiarkan semalam sampai terjadi endapan.

\section{Penyaringan}

Setelah proses pengendapan, kemudian dilakukan penyaringan, filtrat dibuang, endapan dilakukan pencucian.

\section{Pencucian}

Pencucian endapan dilakukan dengan dua cara, yaitu endapan dilakukan pencucian dengan alkohol sampai $\mathrm{pH}$ netral, dan satunya tanpa pencucian atau dicuci dengan air saja.

\section{Pengeringan}

Setelah proses pencucian, kemudian dikeringkan dalam oven pada suhu $60-62{ }^{\circ} \mathrm{C}$, lalu dilakukan Analisis produk pektin.

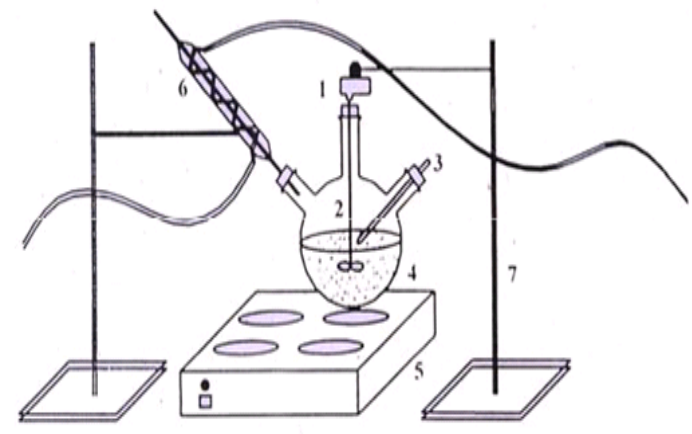

Gambar Rangkaian alat Ekstraksi

'Keterangan Gambar:

1. Motor pengaduk

2. Pengaduk

3. Termometer

4. Labu leher tiga

5. Water bath

6. Kondensor

7. Statif

\section{Hasil dan Pembahasan.}

Dari hasil analisis terlihat pada gambar 1 dan gambar 2.

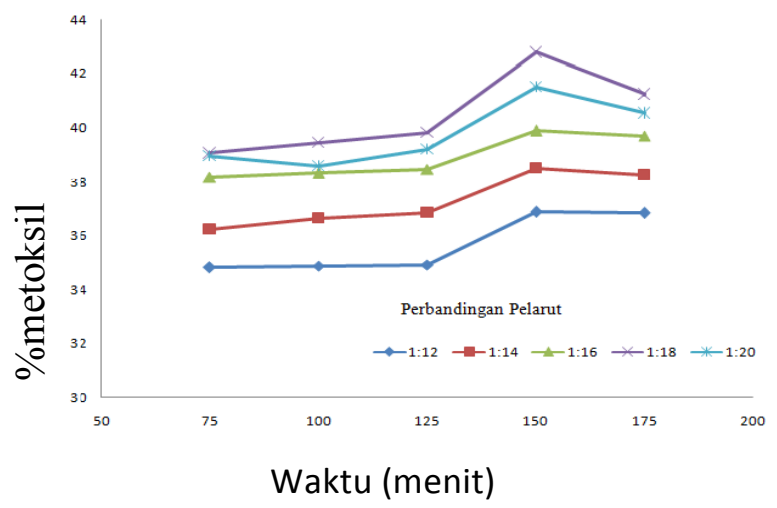

Gambar 1. Grafik Hubungan Antara Waktu Dengan Kadar Metoksil Pada Berbagai Perbandingan Bahan dan Pelarut Asam Sitrat untuk Pencucian Dengan Alkohol.

Berdasarkan hasil analisis pada gambar 1, terlihat waktu 75 menit sampai 125 menit terjadi kenaikan perlahanlahan, namun pada waktu 125 menit sampai 150 menit terjadi kenaikan tajam, hal ini disebabkan semakin banyak 
jumlah pelarut dan waktu ekstraksi yang lama maka kadar metoksil yang diperoleh juga semakin meningkat. Hal ini menunjukkan adanya hidrolisis oleh asam pada kulit Tetapi pada waktu 175 menit, kadar metoksil mengalami penurunan karena kemampuan asam untuk menghidrolisis protopektin menjadi pektin sudah maksimal. Pada pelarut asam sitrat di dapat hasil terbaik kadar metoksil dengan pencucian alkohol sebesar $42,80 \%$ pada perbandingan pelarut 1 : 18 dengan waktu ekstraksi 150 menit. Sedangkan pada perbandingan 1:20 terlihat pada waktu 75 menit sampai 100 menit mengalami penurunan kemudian perlahan -lahan naik terus sampai waktu ke buah coklat dalam jumlah pelarut yang banyak dan waktu yang cukup lama sehingga distribusi partikel akan semakin menyebar dan memperluas kontak permukaan. 150 menit dan setelah itu terjadi penurunan. Hal ini disebabkan pada waktu 75 menit sampai 100 menit proses ektraksi belum terjadi dan memerlukan waktu yang cukup lama, pada waktu 125 menit sampai 150 menit terjadi kenaikan tajam dan kemudian mengalami penurunan, disebabkan pula adanya pengadukan maka difusi akan bertambah dan perpindahan massa dari permukaan partikel kedalam larutan akan bertambah cepat dan kemudian menurun.

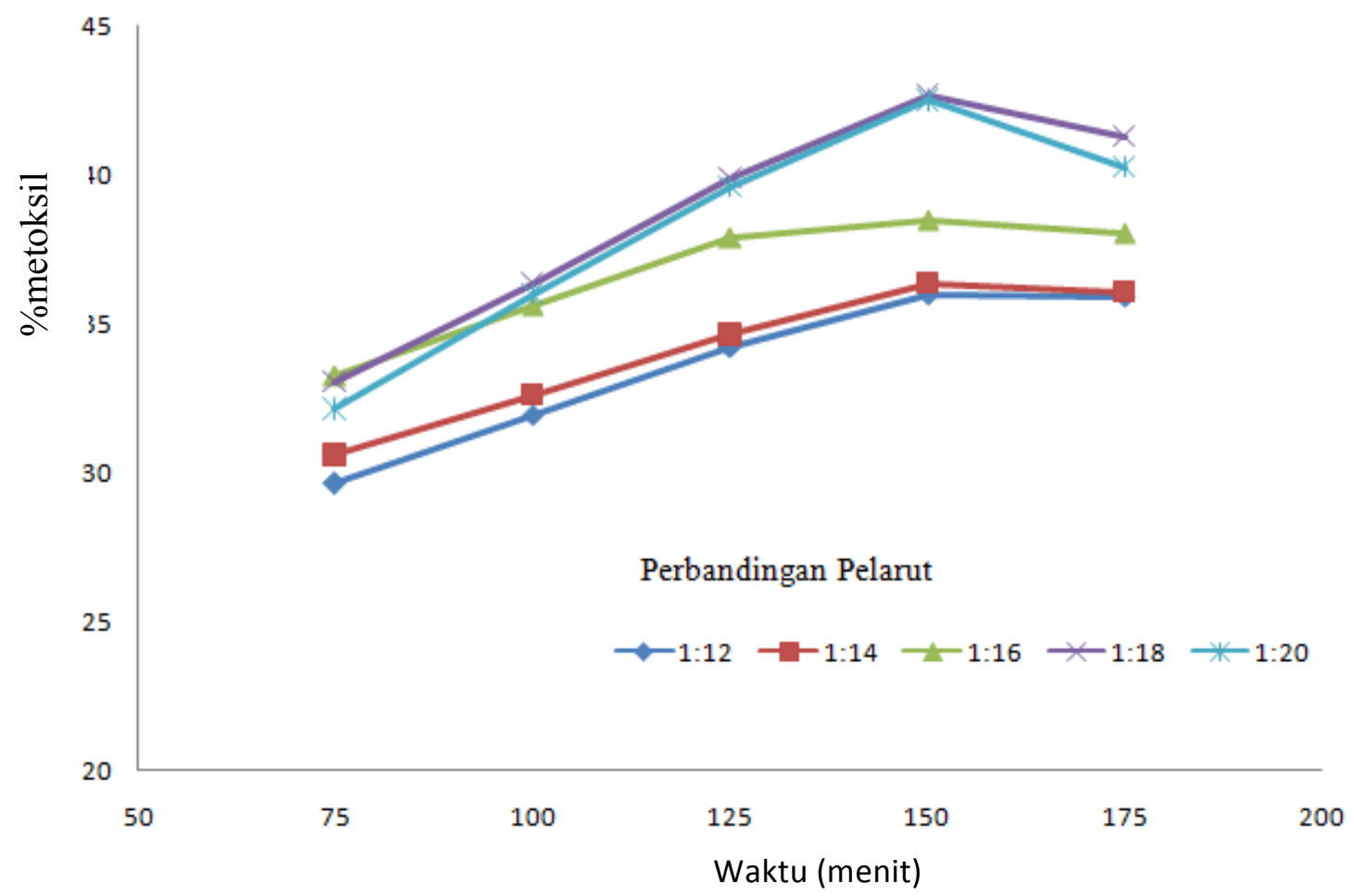

Gambar 2. Grafik Hubungan Antara Waktu Dengan Kadar Metoksil Pada Berbagai Perbandingan Bahan dan Pelarut Asam Sitrat untuk Pencucian Tanpa Alkohol.

Pada gambar 2 , terlihat pada waktu 75 menit sampai 150 menit terjadi kenaikan kemudian mengalami penurunan. Disebabkan semakin lama waktu ekstraksi dan semakin banyak jumlah pelarut, maka kadar metoksil yang diperoleh juga semakin meningkat, Hal ini menunjukkan adanya hidrolisis oleh asam pada kulit buah kakao dalam jumlah pelarut yang banyak dan waktu yang cukup lama maka semakin sempurna pula singgungan anatra pelarut dengan bahan, sehingga ekstrasi yang optimum. Tetapi pada waktu 175 menit, kadar metoksil mengalami penurunan karena kemampuan asam untuk menghidrolisis protopektin menjadi pektin sudah maksimal. Didapatkan hasil terbaik kadar metoksil pencucian tanpa alkohol sebesar $42,68 \%$, perbandingan pelarut 1:18 dan waktu ekstraksi 150 menit. Pencucian dengan alkohol dan tanpa alkohol hasil kadar metoksil hampir sama. Tetapi ada perbedaan dari warna pektin yang dihasilkan, untuk pencucian dengan alkohol jauh lebih bersih, lebih putih bila dibandingkan dengan pencucian tanpa alcohol. 
Tabel.1: Tabel kualitatifperlakuan pencucian dengan alkohol dan tanpa alkohol pada asam sitrat.

\begin{tabular}{|c|c|c|c|c|c|c|c|c|c|c|}
\hline \multirow{2}{*}{$\begin{array}{c}\text { PERBANDINGAN } \\
\text { PELARUT } \\
\text { ASAM SITRAT }\end{array}$} & \multicolumn{5}{|c|}{ PENCUCIAN DENGAN ALKOHOL } & \multicolumn{5}{|c|}{ PENCUCIAN TANPA ALKOHOL } \\
\hline & $75 \mathrm{mnt}$ & $100 \mathrm{mnt}$ & $125 \mathrm{mnt}$ & $150 \mathrm{mnt}$ & $175 \mathrm{mnt}$ & $75 \mathrm{mnt}$ & $100 \mathrm{mnt}$ & $125 \mathrm{mnt}$ & $150 \mathrm{mnt}$ & $175 \mathrm{mnt}$ \\
\hline $1: 12$ & putih & putih & putih & putih & putih & coklat & coklat & coklat & coklat & coklat \\
\hline $1: 14$ & putih kecoklatan & putih & putih & putih & putih & coklat & coklat & coklat & coklat & coklat \\
\hline 1:16 & putih & putih & putih & putih & putih & coklat & coklat & coklat & putih kecoklatan & coklat \\
\hline 1:18 & putih & putih & putih & putih & putih & coklat & coklat & coklat & coklat & coklat \\
\hline $1: 20$ & putih & putih & putih & putih & putih & coklat & coklat & coklat & putih kecoklatan & tith kecoklatan \\
\hline
\end{tabular}

Terlihat pada tabel 1. Bahwa pada pencucian dengan alkohol warna putih lebih dominan bila dibandingkan pencucian tanpa alkohol. Hal ini disebabkan sifat asam pada pektin akan hilang menjadi netral. Karena dicuci dengan alkohol sampai $\mathrm{pH}$ netral.

\section{Kesimpulan.}

Pada pelarut asam sitrat perolehnan kadar metoksil untuk pencucian alkohol 42,80\% ,

sedangkan pencucian tanpa alkohol kadar metoksil didapat $42,68 \%$. Dengan perbandingan yang sama yaitu pada perbadingan bahan dan pelarut $1: 18$. Serta waktu 150 menit. Kadar metoksil juga termasuk golongan pektin metoksil tinggi.yaitu lebih $7,12 \%$ sedangkan pektin metoksil rendah 2,3-4,5.

\section{Daftar Pustaka}

C.Schemin M.H, et al, Extraction of pectin from apple pomace. Brazillian archives of biology and technology, International Journal,Brazil.2005,48(2),259-266

D.Mariaty, Pektin dan pemanfaatannya dalam industri pangan. 2000.

Mc Cabe, Waren L.,Unit Operation of Chemical Engineering.Mc Graw Hill International edition. $2005,7^{\text {th }}$.ed.(764).

Spillane, James J.Dr., komoditi kakao. Kanisius. Yogyakarta.1995.

www.eprint.undip.ac.id/Akmaludin.pdf/ nov. 2011.

www.repository.usu.ac.id/bit stream.pdf/ maret 2012. 